\title{
THE ROLE OF STATE ARBITRAZH UNDER THE NEW CONDITIONS OF ECONOMIC MANAGEMENT IN THE SOVIET UNION *
}

\section{Legal Sources of the Planned Economy}

A department store in Moscow receives defective merchandise from a supplier; a factory fails to deliver an order as scheduled; a shipment of goods to a warehouse in Tashkent is incomplete; or one enterprise deliberately refuses to enter into an agreement with another. These are typical of the disputes that arise between state enterprises and organizations in the Soviet Union. The rapid and just resolution of these conflicts is apparently considered essential to the efficient implementation of the centrally-directed economic plan.

The agency of State Arbitration (Arbitrazh or Gosarbitrazh ${ }^{1}$ ) exists to resolve such disputes between socialist enterprises. The operation and competence of Arbitrazh is best understood by an examination of the Statute on State Arbitration of the U.S.S.R. Council of Ministers. $^{2}$ This statute regulates the Arbitration Department of the

* The author wishes to acknowledge the helpful suggestions of Dr. Herbert S. Levine, Professor of Economics at the University of Pennsylvania, and Alec Nove, Director of the Department for the Study of the Social and Economic Institutions of the U.S.S.R. of the University of Glasgow, Visiting Professor of Economics at the University of Pennsylvania 1967-1968, each of whom read and commented on the manuscript at some stage of its preparation. This paper is considerably improved as a result of their criticism.

1 The Russian word arbitrazh (Gosudarstvenny or Gos-Arbitrazh-State Arbitrazh; Vedomstvenny Arbitrazh-Departmental Arbitrazh; Vneshnetorgovoy Arbitrazh - Foreign Trade Arbitrazh) does not carry the same connotation as does the English word "arbitration.". Soviet State Arbitrazh is a system of specialized economic courts, not conciliation agencies established to bring about compromises between the parties before them. Arbitration tribunals in the Western sense have been established in the Soviet Union and are known as treteiskiye sudy or courts of conciliation. See text accompanying notes 104-10 infra. In this Comment, State Arbitrazh or Gosarbitrash will be used to refer to the structure and procedure of the economic courts. A state arbitration tribunal, which tribunals exist at the local, regional, republican and union level, will be referred to as an arbitrazh.

2 Statute on State Arbitration of the U.S.S.R. Council of Ministers, [1961] Zak. Akty 745 (Legislative Acts 1960), 2 Sov. Stat. \& Dec. No. 1, at 5 (1965); J. HAzARD \& I. SHAPIRo, THe Soviet LEGAL SySTEM (pt. 2, at 113-16 (1962) [hereinafter cited as Hazard \& Shapiro]; 12 CurRent Digest of THe Soviet Press, No. 42, at 15 (1960). This statute replaced the law in effect since 1931 .

There are also rules for arbitrazhy, see, e.g., Rules of Consideration of Economic Disputes by State Arbitrazhy, [1964] Instr. Ukaz. 24 (Directive Instructions of State Arbitrazh of the U.S.S.R. Council of Ministers 1963), 2 Sov. StaT. \& DEc. No. 1, at 26 (1965). The rules are based upon the maximum democratization of the arbitration process and, therefore, encourage voluntary and direct settlement of disputes. Various rules have received considerable discussion in Soviet legal periodicals. See Barash, Commentary on the Rules for the Consideration of Economic Disputes by State Arbitration Agencies, [1963] 20 SovetskaYa IUSTITSIYA [Sov. IUsT.] 18, translated in 2 Sov. L. \& Gov'r No. 4, at 55 (1964); Falkovich, Commentary on the Rules for the Consideration of Economic Disputes by State Arbitration Agencies, [1963] 18 Sov. 
Council of Ministers of the U.S.S.R., the ultimate arbitral tribunal in the Soviet Union. State Arbitrazh has competence, subject to a jurisdictional amount, ${ }^{3}$ to hear disputes between (1) enterprises in different republics, or (2) enterprises which are subordinated to different departments or ministries. ${ }^{4}$ The union republics and autonomous regions have arbitration structures similar to that of the U.S.S.R. Council of Ministers. ${ }^{5}$

Arbitrazh operates at either of two stages: during contract negotiations or following a breach of contract by a state enterprise. ${ }^{\circ}$ In the pre-contract cases, Arbitrazh forces a reluctant enterprise to enter into a contract with a willing partner, or settles disputes over draft contracts. $^{7}$ After a contract is breached, Arbitrazh applies property sanctions ${ }^{8}$ and, in certain circumstances, refers the matter to the Procurator General for possible criminal sanctions against individual managers of enterprises. ${ }^{9}$

IUsT. 16, translated in 2 Sov. L. \& Gov'T No. 4, at 55 (1964) ; Petrov, Commentary on the Rusles for the Consideration of Econonic Disputes by State Arbitration, [1964] 5 Sov. Iust. 17, translated in 3 Sov. L. \& Gov'T No. 2, at 38 (1964), 5 Sov. REv. No. 4, at 40 (1964) ; Shapkina, Commentary on the Rules for the Consideration of Economic Disputes by State Arbitration, [1964] 4 Sov. IUST. 14, translated in 3 Sov. L. \& Gov't No. 2, at 38 (1964), 5 Sov. Rev. No. 4, at 40 (1964).

3 The amount in dispute must be greater than 1,000,000 (post-1961) rubles, about $\$ 1,100,000$, in pre-contract cases, and 10,000 (post-1961) rubles, about $\$ 11,000$, in completed contract cases. Statute on State Arbitration of the U.S.S.R. Council of Ministers $\$ \$ 3(\mathrm{a}), 3(\mathrm{c})$, [1961] Zak. Akty 745 (Legislative Acts 1960), 2 Sov. STAT. \& Dec. No. 1, at 5 (1965), Hazard \& Shapiro 113-16, 12 Current Digest of the Soviet Press No. 42, at 15 (1960). These amounts limit jurisdiction of the State Arbitrazh of the U.S.S.R. Council of Ministers. Local, regional and republican arbitrazhy have varying maximum and minimum jurisdictional amounts. Cf. note 103 infra and accompanying text. Disputes involving less than the jurisdictional amount are settled administratively within the Ministries or Departments involved. Johnson, Planning and Contract Law, 12 Sov. STudres 263 \& n.6 (1961).

4 Departmental or Agency Arbitragh has jurisdiction over disputes between enterprises in a single Ministry or Department of the U.S.S.R. State Arbitrazh must not accept such cases for consideration, and a mistakenly accepted dispute is not subject to a decision on the merits by Arbitrazh. Kokandsky Shoe Factory v. Dzhambulkozhobuv Combine (State Arbitration of the U.S.S.R. Council of Ministers 1966), in [1967] 7 Sov. IUST, 32.

5 The U.S.S.R. is a federation of 15 republics, the largest of which is the Russian Republic (R.S.F.S.R.). The codes and statutes vary little from republic to republic. For other Arbitrazh statutes, see, e.g., Statute on State Arbitration of the R.S.F.S.R. Council of Ministers (1960), [1961] 2 Sov. IUST. 25, translated in part in HAZARD \& ShapIRo 116. Republican arbitration tribunals are concerned with disputes between enterprises in the same republic.

"Arbitrazh is one form of "legal control," over the administration of the economic bureaucracy. The others are the ordinary courts and the Procuracy. The Procurator General has supervisory power over the execution of the laws. See M. FAINSOd, How Russia Is RULed 411-14 (2d ed. 1963).

${ }^{7}$ Loeber, Plan and Contract Performance in Soviet Laze, 1964 U. ILL. L. F. 128; 146, reprinted in LAw IN THE Soviet Society 128 (W. LaFave ed. 1965).

${ }^{8}$ For example, fines can be exacted from defaulting enterprises and specific performance of the terms of delivery contracts may be awarded. Arbitrazh also grants damages for tort claims of one enterprise against another.

9 Procedure for Forwarding to Agencies of the Procuracy Notices of Instances of Delivery of Poor Quality and Incomplete Products, [1964] Instr. Ukaz. 248 (Direc- 
In both these situations, the conflict and interaction between the economic plan and the law of contracts is vivid.10 Lenin's critical adaptations of Marxism to the immature Tsarist Russian economy, ${ }^{11}$ as implemented by Stalin's forced collectivization and rapid industrialization of Soviet Russia, are the origins of the centrally-planned economy. The prime objective and initial emphasis of the political leaders was rapid growth of producers' goods. In accordance with the directives of those leaders, the production of goods for current consumption was sacrificed to the development of heavy industry. The legal embodiment of the command economy ${ }^{12}$ is article 11 of the Constitution of the U.S.S.R., which provides:

The economic life of the U.S.S.R. is determined and directed by the state national economic plan, with the aim of increasing the public wealth, of steadily raising the material and cultural standards of the working people, of consolidating the independence of the U.S.S.R. and [of] strengthening its defensive capacity. ${ }^{13}$

tive Instructions of State Arbitrazh of the U.S.S.R. Council of Ministers 1949), 2 Sov. STAT. \& Dec. No. 1, at 79 (1965). The basis of the power of Arbitrazh to make such referrals is that incomplete and substandard deliveries cause loss to the state. See R.S.F.S.R. 1961 UgoL. KoD. (Criminal Code) art. 170, which makes criminal "malicious use of power or of a responsible position ... if causing substantial harm to state or public interests. ...."

A British lawyer has reported that the main criticism of Arbitrazh by Soviet commentators is that the arbitrators do not make full use of their power to report infringements to the Procuracy. Johnson, Commercial Arbitration in the U.S.S.R. since the Decentralization of Industrial Management, 11 Sov. Studres 134, 135 (1959). This has been subsequently corroborated. E.g., Liberman, Arbitration Practice in Cases Involving the Quality and Completeness of Production, [1963] 12 SOVETSKoye Gosudarstvo I Pravo [Sov. Gos. I Prav.] 132, 3 Sov. L. \& Gov't No. 2, at 47, 54 (1964).

10 In light of the significance of contracts in the Soviet Union, it is revealing to note that the first of the "primary tasks" enumerated in the Statute on State Arbitration is "to assure the protection of the property rights and legal interests of enterprises and organizations in the decision of economic disputes." The second "primary task" makes reference to "[c]ollaboration ... for fulfillment of the national economic plan ...."-indicating that the protection of "property rights," including contract rights, is at least as important as fulfillment of the plan. Statute on State Arbitration of the U.S.S.R. Council of Ministers $\$ \$ 2(a)-(b)$, [1961] Zak. Akty 745 (Legislative Acts 1960), 2 Sov. Stat. \& Dec. No. 1, at 5 (1965), Hazard \& Shapiro 113-16, 12 CurRent Digest of the Soviet Press No. 42, at 15 (1960).

11 Marx never formulated any rules for operating an economy; centralized economic planning is certainly not an essential part of Marxism. See generally Berliner, Marxism and the Soviet Economy, in THE SovieT Economy 18-33 (M. Bornstein \& D. Fusfeld eds. 1966).

12 The term "command economy" applies to the implementation of the plan rather than to plan construction. Levine, Economics, in ScIENCE AND IDEOLOGY IN SOVIET SOCIETy 107, 112 (G. Fischer ed. 1967).

13 Two Soviet legal commentators in their annotation to this provision have noted that central planning ensures: (1) coordination of all branches of the economy; (2) technical progress; (3) rational distribution of the productive forces; and (4) improvement in the well-being of the working people. A. Denisov \& $M$. KIRICHENko, Soviet State Law 126-27 (1960). See also R.S.F.S.R. 1964 GrazH. Kod. (Civil Code) art. 1 (para. 2): "The economic life of the RSFSR is regulated and directed by the state national economic plan." 
Article 9 reaffirms that the socialist economy predominates ${ }^{14}$ in such a society, it is clear that planning acts have the force of law. ${ }^{15}$

Since the inauguration of "the plan as law," 16 the fundamental problem has been the determination of' which details of the relations between state enterprises should be controlled at the central planning headquarters. ${ }^{17}$ Although Russian commercial law is essentially the civil law of obligations, ${ }^{18}$ the official thinking about the role which contracts play in the planned economy has varied from one of fully-planned relations precluding contracts ${ }^{19}$ to the obligatory drafting of complex documents by the contracting partners. ${ }^{20}$

However, this system, which presupposed the planned economy as law, is finding that the traditional forms of planning are becoming obsolete. ${ }^{21}$ Managers of certain Soviet enterprises no longer receive incredibly detailed instructions from the central planning headquarters; instead, they are free to solve many problems for themselves, hopefully gearing their operations to the ability to sell their products. The key indicator of success is the volume of sales of the enterprise, ${ }^{22}$ rather than the fulfilment of production targets. It is now recognized that not every detail of production can be planned-not every nut and bolt in the Soviet Union can be accounted for by the planners in Moscow. ${ }^{23}$ Consequently, contractual relationships between enterprises are encouraged; in fact, sometimes ordered. ${ }^{24}$

14 Alongside the socialist system of economy, which is the predominant form of economy in the U.S.S.R., the law permits the small private economy of individual peasants and handicraftsmen based on their own labour and precluding the exploitation of the labour of others.

U.S.S.R. CONST. art. 9.

15 A. Denisov \& M. KIRIChenko, supra note 13, at 127.

16 The first "Five-Year Plan" was begun in 1928, although the first federal constitution of the U.S.S.R. authorized the union government to create a central economic plan in 1923. J. HAZARD, THE SOVIET SYSTEM OF GOVERNMENT 86 (3d ed. rev. 1967).

17 Gosplan is the Russian acronym for the State Planning Committee. On the organization framework of the operation of the Soviet economy, see A. Nove, THE SovIET ECoNomy 75-78 (rev. ed. 1965).

18 Although the law of the Soviet Union does differ in many respects from the civil law, there are, in contrast to the common law, striking similarities between civil and Soviet law.

19 This was the original thought in 1928.

20 See Hazard \& Shapiro 96-100.

21 R. Campbeli, Soviet Economic Power: Its Organization, Growth and Cerallenge 104 (1966).

22 For a fuller discussion of the economic reform, see text accompanying notes 79-148 infra.

23 Until recently, other socialist states of Eastern Europe have also had rigidly controlled, centrally planned economies. Their method of economic organization also involves civil law contracts, a form of "market socialism." See Wagner, The Law of Contracts in Communist Countries (Russia, Bulgaria, Caechoslovakia, and Hungary), 7 Sr. Lours U.L.J. 292 (1963); Mihaly, The Role of Civil Law Institutions in the Management of Communist Economies: The Hungarian Experience, 8 AM. J. CoMP. I. 310 (1959).

$24 \mathrm{H}$. Berman, Justice IN THE U.S.S.R. 123 (1963) [hereinafter cited as BERMAN]. A concise discussion of the law of contract in the Soviet Union concludes that, even though contracts may be entered into on a large scale, legal remedies are 
Since contracts now play an increasingly important role in the planned economy, this Comment will discuss published reports of decisions of State Arbitrazh ${ }^{25}$ in order to elucidate the types of breaches that provoke complaints, the defenses that are available and the manner in which disputes are presently resolved. This discussion will be followed by a dialogue, indicating the reconciliation of the conflicting concepts of increased independent decision-making for enterprise directors and the role of Gosarbitrazh as the monitor of inter-enterprise relationships under the recent reform of economic management.

\section{The Obligation to Perform}

Two relationships are involved in the contracting procedure, the first between the superior planning agency and its operating enterprise (supplier or purchaser) and the second between that enterprise and another enterprise. The planning agency sends a fond-notification (a fond is the right to receive materials and credit over a given period of time) to its subordinate enterprise, indicating the materials and funds allocated to the enterprise for the planning year. After the enterprise specifies its needs within the allocated fond, the superior issues a naryad, or order to deliver particular types or amounts of goods to other enterprises. ${ }^{26}$ Between the planning agency and Enterprise No. 1 (the supplier, for example), the obligation is to perform the planned task-to manufacture $X$ tons of steel or $Y$ refrigerators. As far as this relationship is concerned, it is clear that the obligation stems from the planning act as expressed in an order, the naryad; the planning organ and the recipient of the plan are not contract partners. ${ }^{27}$

The normal procedure for entering into an economic contract is for the supplier, after receiving a naryad from its superior agency, to draft a contract and send it to the purchaser. ${ }^{28}$ If the purchaser disputes a term in the contract or refuses to conclude a contract altogether, it prepares a "Protocol of Disagreement" and sends it to the supplier-

not pursued zealously. See Zile, Law and the Distribution of Constmer Goods in the Soviet Union, 1964 U. ILL. I. F. 212, 234-40, reprinted in LAW IN THE SOVIET SOCIETY 212-76 (W. LaFave ed. 1965). This has been corroborated by [1965] 5 Radyanskoye Pravo 14, translated in part in 17 Sov. Studies No. 9, at 13 (Information Supp. Jan. 1966).

25 Arbitrazh decisions are selectively reported in the official Gazette of the State Arbitrazh of the U.S.S.R. Council of Ministers, Sbornik instruktivnykh ukazanii gosudarstvennovo arbitrizha pri Sozete ministrov S.S.S.R. (Collection of Directive Instructions of State Arbitrazh of the U.S.S.R. Council of Ministers) [hereinafter cited as Sbornik (Collection)], as well as being summarized in the legal periodicals. ordinate.

28 The naryad may specify the other enterprise or leave the choice to the sub-

27 Even so, it now may be possible for an enterprise to object to a planning order. See text accompanying notes 115-21 infra.

28 The purchaser's superior also may issue a naryad, which "gives the purchaser organization the right to place an order (zakaz) for the goods. Ôn the basis of the naryad, and of the zakaz, if sent, the parties enter into contracts of delivery . . . ." 2 Sov. StaT. \& DEc. No. 2, at 1-2 (1965). 
enterprise. If the supplier agrees to the changes, a contract is concluded, incorporating the protocol. If the supplier does not agree, he has recourse to Arbitrazh to settle the disputed term or to compel the purchaser to conclude the contract. ${ }^{29}$

The relationship between Enterprise No. 1 (the supplier) and Enterprise No. 2 (the purchaser) is based solely on the contract between them; the planning act neither gives any rights to, nor imposes any obligations on, Enterprise No. 1 vis-à-vis Enterprise No. 2. The right of the seller to demand payment from the buyer and the right of the buyer to demand delivery from the seller both emanate from the contract. Thus, the obligation upon an enterprise to perform its planned task is created by the planning act, whereas the obligation to perform for another economic entity is created by the contract between the entities.

\section{Pre-Contract Disputes}

In the pre-contract cases, Arbitrazh settles disputes over draft contracts or forces a reluctant enterprise to enter into a contract with a willing partner. A frequently disputed term in draft contracts is the time of delivery of goods. Typical is a case in which the Delivery Section of the Tadzhik Economic Council was required by its plan to conclude a contract with the State Plant of the Leningrad Economic Council for delivery of cottonseed oil. ${ }^{30}$ The seller proposed shipments of equal amounts once a month, but the buyer requested shipments once every ten days because it could not store larger shipments. State Arbitrazh of the Turkmen S.S.R. Council of Ministers decided in favor of the seller because the railroad provided him with tank cars only once a month. ${ }^{31}$ On appeal to Arbitrazh of the U.S.S.R. Council of Minsters, this decision was reversed, the Chief Arbiter requiring a provision for equal shipments twice a month.

What is crucial to the appellate decision is the fact that the Chief Arbiter had the power to order administrative agencies to arrange their affairs to effectuate the decision. In this case, he called upon the Director of the Tashkent Railroad to provide the seller with tank cars twice a month. By doing something neither of the parties could, the arbiter was doing more than merely effecting a compromise between the contracting parties. There were two ways of resolving the con-

29 On the planning and contract procedure, see Loeber, supra note 7, at 134-48; BERMAN 122-24.

30 Delivery Section of the Tadzhik Economic Council v. State Plant of the Leningrad Economic Council, [1960] Sbornik 33 (Collection), BERMAN 132-33.

31 Apparently, there are tremendous difficulties connected with the provision of railroad cars. It was considered worthy of report that, in 1966, the Moscow Plant Likhachev failed to receive more than 1300 railroad cars. Pogosov, Certain Results and Problems of Industrial Economic Reform, [1967] 7 Vestnik STATISTIKI 19, translated in JoInt Publications Research SERvice, U.S. DeP'T of Commerce and INDUSTRY, GENERAL INFORMATION 11, 16 (PUB. No. 42,605, 1967). 
flict: enlarging the storage facilities of the purchaser, or providing more frequent railroad service. In this case, "neither party really suffered a defeat;" ${ }^{32}$ the Tashkent Railroad was the only entity that could have suffered, since it may have been forced to reallocate cars from another customer in order to comply with the Chief Arbiter's decision. ${ }^{33}$

Another pre-contract dispute involved a clause in the contract of a bottler of wine and soft drinks which required the purchaser to return as empties no more than 100 per cent of bottles sold to it. ${ }^{34}$ The purchaser complained that it had no control over the number of bottles returned by the public. State Arbitrazh decided that the contract could contain no limit on the number of bottles returned, but warned the bottler that it should not allow large numbers of returned bottles to accumulate, and that it must ask its superior planning organ how to dispose of surplus bottles. Again, one sees the arbiter going beyond the two disputing parties and tailoring a result which is mutually agreeable, but involving an imposition upon a third party.

State Arbitration may also force an unwilling enterprise to enter into a contract. The Moscow Wholesale Depot "Roskhoztorga" requested State Arbitrazh of the R.S.F.S.R. Council of Ministers to require a chemical factory to negotiate a contract for the delivery of plastic products in $1966 .^{35}$ The chemical factory hesitated because of the lack of raw materials set aside for its own plan of production. The buyer relied on its plan of production and the fact that the goods were in tremendous demand and were sold in advance by trading organizations.

Arbitrazh compelled the factory to enter into a contraci with the depot, referring to the fact that the absence of materials could be

82 BERMAN 133.

33 The other customer would apparently be able to recover its losses from the railroad. See notes 39-43 infra and accompanying text.

Another compromise decision was obvious in a dispute over the time for delivery of machines to a shipyard. The machine building plant was required to supply one machine in each of the second, third and fourth quarters of 1958. The supplier requested a change to no delivery in the second quarter, one machine in the third quarter and two machines in the fourth quarter. The shipyard agreed by telegram, but rejected the change upon signing the contract. State Arbitrazh of the U.S.S.R. Council of Ministers decided, on appeal, that the decision of the lower arbitrazh, upholding the original arrangement, was unrealistic since its decision was handed down on June 20 , ten days before the end of the second quarter. The machine plant was allowed to deliver one unit in August and the remaining units according to the revised schedule. Machine Building Plant v. Shipbuilding Plant, [1959] Sbornik 37 (Collection 1958), 2 Sov. STAT. \& DEC. No. 3, at 20 (1966).

34 Pre-Contract Request of Leningrad Provincial Arbitration for Advice (State Arbitration of the R.S.F.S.R. Council of Ministers 1960), in [1961] 7 SotsialistrCHeskaya Zakonnost [Sots. Zak.] 92, 2 Sov. Stat. \& DEc. No. 3, at 23 (1966), HAZARD \& SHAPIRO 125-26.

35 Moscow Wholesale Depot "Roskhoztorga" v. Moscow Chemical Factory "Khimfoto" (State Arbitration of the R.S.F.S.R. Council of Ministers 1966), in [1966] 20 Sov. IUST. 33. 
investigated upon the consideration of disputes about the exaction of sanctions for nondelivery of finished products, rather than upon the entering into of contracts. ${ }^{36}$ State Arbitrazh also requested the superior organizations of the chemical factory to guarantee the raw materials prescribed by plans of production.

These decisions bear out Professor Dietrich Loeber's theory that

[d] isputes before Arbitrazh are not necessarily legal in character; they may also involve questions of economic expediency .... Arbitrazh decisions have often an operative rather than a judicial character: they are part of the day-today economic administration. ${ }^{37}$

The "operative character" of pre-contract decisions means that they operate not only on the contracting parties to conclude contracts or to resolve a contract term, but also on others to effectuate the resulting contract. The decision to impose upon other enterprises and agencies the obligation to aid in the fulfillment of delivery plans ${ }^{38}$ is "not necessarily legal in character," but is based on economic expediency as well.

\section{Non-Conforming Deliveries}

\section{Absence of Raw Materials}

In many situations, delay or nondelivery by prime suppliers is connected with the tardy or nonreceipt of raw materials or units of semi-finished goods from superiors or from cooperating enterprises designated by them.

Ordinarily, the factual impossibility of performing a task is no defense to an action for breach of contract brought by a purchaser. In Moscow Woolen Base v. Troitsky Cloth Factory, ${ }^{39}$ the purchaser sued for damages resulting from nondelivery of woolen cloth. The supplier defended on the ground that its superior did not allocate sufficient raw materials to enable it to fulfill the contract with the purchaser; in other words, the fault lay with the supplier's superior, not with the supplier. The R.S.F.S.R. State Arbitrazh rejected this argument and decided that the supplier was liable. The tribunal explained that the mere absence of raw materials does not serve to relieve the supplier from liability unless the supplier shows that it has done all it can to secure infra.

36 This principle might not be followed today. See text accompanying notes $115-24$

37 Loeber, supra note 7, at 146.

38 This is one of the "primary tasks" of State Arbitration. Statute on State Arbitration of the U.S.S.R. Council of Ministers \$2 (d), [1961] Zak. Akty 745 (Legislative Acts 1960), 2 Sov. StaT. \& DEC. No. 1, at 5 (1965), HazArd \& SHapIro 113-16, 12 Current Digest of the Soviet Press No. 42, at 15 (1960).

39 (State Arbitration of the R.S.F.S.R. Council of Ministers 1965), in [1966] 11 Sov. IUST. 31. 
materials from the superior. ${ }^{40}$ Professor Loeber describes such a result as "harsh," but necessary-"to decide otherwise would allow producers to use shortcomings of planning authorities as [an] . . . excuse for their own failures . . . and to rely . . . on the mechanisms of planning." 41

On its face, the Moscow Woolen decision appears to ignore the requirement of the Russian Civil Code that there be no contractual liability without fault. ${ }^{42}$ This apparent contradiction has been explained by Professor Harold Berman:

Despite the general requirement that there is no liability for breach of contract without fault, the failure of the supplier's own sources of supply is not considered to be a valid excuse for his nonperformance; in such cases a fictitious fault is assumed to exist. ${ }^{43}$

The theory is that the seller and its superior are a single entity, thus depriving the seller of the defense that its superior, and not itself, was at fault. In this sense, however, all agencies and enterprises in the Soviet Union are ultimately one; all are subordinate to the highest economic organ, the Council of Ministers. But the individual enterprises at the lower levels do enter into contracts with each other; they are capable of suing and being sued; and money sanctions are applied against them. In short, the fault is "fictitiously" attributed to the operating enterprises, which have an independent existence in their contractual relations and are separate from their superiors.

A purchaser was held responsible for the faults of its superior in Suit of Tikhoinsky Aluminum Factory. ${ }^{44}$ In that case the factory was required to supply the purchaser with 170 tons of polishing com-

40 In a suit by a producer of insulating materials for damages for incomplete delivery, the defense again was that the supplier had not been provided with raw materials by its superior; in spite of this, defendant delivered all it could. The lower arbitrazh found that plaintiff did not attempt to use other raw materials in the manufacture of insulating materials. On appeal, a decision for defendant was affirmed by the Deputy Chief Arbiter of the U.S.S.R. Council of Ministers. Kharkov Factory "Elektrotiazmash" v. Bobrovsk Insulation Factory (State Arbitration of the U.S.S.R. Council of Ministers), in [1960] 12 Sots. ZaR. 77, HazARD \& ShapIRo 127-28, 2 Sov. STAT. \& DEC. No. 3, at 38 (1966).

In the spirit of the educative role of State Arbitrazh, see the tasks set out in the Statute on State Arbitration of the U.S.S.R. Council of Ministers, [1961] Zak. Akty 745 (Legislative Acts 1960), 2 Sov. Stat. \& Dec. No. 1, at 5 (1965), HAzard \& Shapiro 113-16, 12 Current Digest of the Soviet Press No. 42, at 15 (1960). Attention of the directors was called to the poor performance of the factories in this case. The planning agencies were asked to coordinate the production and requirements of all the enterprises which manufacture insulating materials.

41Loeber, supra note 7, at 148. In addition, Professor Harold Berman has sug. gested that this approach is intended to encourage enterprises to press claims for damages against defaulting suppliers and thus recoup losses which they suffer by virtue of their own breach of contract. BERMAN 136. See text accompanying note 46 infra. 42 R.S.F.S.R. 1964 GrazH. Kod. (Civil Code) art. 222.

43 BERMIAN 136.

44 (State Arbitration of the Bryansk Executive Committee 1966), in [1967] 20 Sov. Iuss. 32 . 
pound in the second to fourth quarters of 1966. In fulfillment of the contract, the supplier shipped 93.7 tons of compound on August 1, 1966. The purchaser refused to accept the remaining shipments, referring to a change in the technology of production and a fear that its fondy would be removed by its superior agency-that is, that the products could not be paid for.

The change of fondy did not come about and the supplier brought suit for a fine in State Arbitrazh for the Bryansk Region based on section 74 of the Statute on Deliveries of Products Intended for Production and Technical Uses. ${ }^{45}$ The lower arbitration tribunal held for defendant-purchaser, since the plaintiff-supplier was required by the contract to make further shipments to the purchaser, and had failed to do so. Upon reconsideration by the Chief Arbiter, the plaintiff's common sense argument that it would be inexpedient and wasteful to ship goods to a purchaser who does not want them and cannot pay for them was rejected. The Chief Arbiter described this as a unilateral refusal on the part of the plaintiff-supplier to perform its contractual obligations.

However, State Arbitrazh of the R.S.F.S.R. Council of Ministers, in a letter to the Bryansk Arbitrazh, noted that refusal to receive contracted-for goods, in violation of the supplier's plan, complicated realization of the planned production. Since the purchaser could not "document" its claim concerning the removal of fondy, it could not demonstrate the exceptional circumstances which would free it from liability. The decision, therefore, was reversed, and a fine was exacted from the purchaser. The shortcomings of its superior in this case were no excuse for the purchaser to breach its contractual obligations to other enterprises.

Fictitious fault may also be attributed to defaulting suppliers or cooperating enterprises. A Machine Building Plant brought suit for the exaction of the price of reactors shipped to a chemical combine. ${ }^{46}$ The combine opposed the suit, referring to the fact that the reactors and apparatus were shipped incomplete-without bottom corner locking valves. At the same time, it filed a counter-claim, asking for (and receiving) a penalty for the supplier's delivery of an incomplete product.

In its petition for reconsideration, the plaintiff-supplier advanced three arguments for collecting the invoiced amount: (1) the construction of reactors was a complicated matter; (2) a sub-supplier, the Myshega Armature Works, was supposed to prepare the valves, but did not fulfill its obligation; and (3) it undertook measures for the

45 This provision provides for a fine of $3 \%$ of the value of the goods the intended recipient refuses to receive. Decree of May 22, 1959, Statute on Deliveries of Products recipient refuses to receive. Item 68 (Collection of Decrees of the U.S.S.R. Council of Ministers), 2 Sov. Stat. \& DEc. No. 2, at 23, 54 (1965).

46 Bolokhovsky Machine-Building Plant v. Vinnitsky Chemical Combine (State Arbitration of the U.S.S.R. Council of Ministers 1965), in [1966] 4 Sov. IUST. 31. 
immediate shipment by the armature factory to the purchaser in order to complete the product. Plaintiff's complaint was reviewed by the Deputy Chief Arbiter of the State Arbitrazh of the U.S.S.R. Council of Ministers and rejected since the plaintiff did not fulfill its obligation to make the reactors complete with valves within fifteen days of delivery. The contract had specified that the equipment must be complete with valves prepared by the Myshega Works, and without these parts the supplier did not have the right to ship the reactors.

An enterprise, then, may force a supplier in another hierarchy to provide it with the materials to enable it to fulfill the plan and its contracts or may sue the supplier for failure to do so. But when the fault of a superior planning agency is attributed to an operating enterprise, the inferior does not have the power to bring suit in State Arbitration against a superior in the same hierarchy; ${ }^{47}$ such disputes are usually resolved by administrative instructions. ${ }^{48}$ The enterprise manager can either say to his superior, when he has been charged with a breach of contract, "it is your fault that I could not fulfill my contract, and you should compensate me for that," or he can apply for instructions as to how to fulfill his contractual obligations before they are breached. ${ }^{49}$

\section{Change of Planning Act and Notice of Non-Conforming Delivery}

Early, late or incomplete deliveries may be justified by changes in planning acts if the changes are agreed upon by the superior agencies of the disputing enterprises or if the changes are made by an agency superior to both enterprises. In Novo-Kramatorskiy MachineBuilding Plant $v$. Izhorskiy Plant, ${ }^{50}$ the seller contracted to deliver three sets of equipment to the buyer. Two more sets, to be delivered in the second half of the year, were ordered by the superior agency of the buyer. Seller informed the buyer of this change before the date of delivery, but the buyer still refused to accept the additional sets of equipment. The seller brought suit to recover his costs. The arbitration agency decided that the buyer was liable for costs of the seller,

47 A. Nove, The Soviet Economy 99 (rev. ed. 1965). But see the discussion in text accompanying notes 114-24 infra.

48 These relationships are usually referred to as matters of administrative law, as opposed to the relations between the contract partners, which are governed by the civil law of obligations. See Loeber, supra note 7, at 145-46.

49 Cf. Moscow Wholesale Warehouse v. Odessa Warehouse, [1959] 11 Sbornik 37 (Collection), in Loeber, supra note 7, at 156, in which a superior agency, the Ukrainian Trade Organization, was required by State Arbitrazh to find another purchaser for an additional 3000 cameras it ordered its subordinate not to accept. The plan of distribution called for plaintiff to deliver 7400 cameras; defendant disagreed with the terms and refused to accept more than 4400 cameras. Arbitrazh held that the defendant was required to buy 7400 cameras.

For a discussion of the subsequent treatment of the fictitious fault doctrine, see text accompanying notes $125-36$ infra.

50 [1957] 6 Sbornik 38 (Collection), in Loeber, supra note 7, at 157. 
since he did not refuse to accept the goods until after the seller had begun to incur costs.

Professor Loeber has stated that the reason for the decision was that the change in the plan was agreed upon by the superior agencies of both contracting parties. ${ }^{51}$ This situation is hybrid-the duty to perform imposed by the planning agency actually altered the contract between the parties to create rights and obligations between the two enterprises. ${ }^{52}$

A case to be considered with Novo-Kramatorskiy Machine-Building Plant is Warehouse in Latvian SSR v. Penza Warehouse, ${ }^{53}$ in which two wholesale warehouses entered into a contract for the delivery of 10,000 ladies' watches (4,000 in gold and 6,000 in steel cases). The All-Union Chief Trade Administration, an agency superior to both contracting parties, ordered the seller to ship 7,600 gold and 1,000 steel watches. The buyer sued the seller for failing to deliver 1,400 watches.

State Arbitrazh held that the seller was not liable because the agency which changed the plan had supervision over both enterprises and because the change was, in effect, incorporated into the contract of both parties. ${ }^{54}$ In Novo-Kramatorskiy, the change was ordered by the superior of the buyer, and the seller sued. Here the change was ordered by the superior of both enterprises, and buyer sued. In both cases, the enterprise whose superior ordered a change in the production or delivery plan prevailed; in both cases there was collaboration of sorts by the superior agencies-in the latter case, the same agency was superior to both parties.55

There are many disputes involving refusal to accept or to pay for accepted goods and, apparently, fulfillment of the notice requirement

51 Loeber, supra note 7 , at 157.

52 The approach Arbitrazh follows is to consider conditions essential to a legal relationship established by the plan as having been stated in the contract. In other words, absence of agreement as to the conditions is no reason for regarding the contract as not having been completed. When two enterprises reach an agreement in conflict with the plan, the entire contract, or the portion which contradicts the plan, is regarded as invalid. Zamengof, Combining Guidance by State Plan and Economic Independence in Contractual Relationships, [1963] 2 Sov. Gos. I PRAv. 33, translated in 2 Sov. L. \& Gov'T No. 1, at 27, 29 (1963).

53 [1960] 14 Sbornik 58 (Collection), in Loeber, supra note 7, at 156.

54 See also Construction Administration of Belovo GRES v. Belovshakhtstroi Trust (State Arbitration of the R.S.F.S.R. Council of Ministers), in [1962] 11 Sors. ZAR. 92, in 2 Sov. STAT. \& DEc. No. 3, at 34 (1966), in which the R.S.F.S.R. Council of Ministers changed a construction plan, thereby relieving the purchaser of liability for nonfulfillment of contract obligations.

55 In another dispute, local arbitrazh decided that 1,000 armature drives had to be delivered, not 1,230, as provided in the contract. State Arbitrazh of the R.S.F.S.R. Council of Ministers found that a modified order called for delivery of only 587, and since the supplier, defendant in a suit for fines for failure to deliver, had delivered at least that number, the suit was rejected. The agency from which the modified distribution order came is not evident from the report of this case, but to be consistent with the cases discussed, see text accompanying notes 48-52 supra, it would have to be assumed that the change came from an agency superior to both enterprises, or was agreed to by two superior agencies and automatically affected the contractual obligations. Myshega Armature Works v. Venikov Armature Works, in Zamengof, supra note 52 , at 35 n. 24 . 
of the Russian Civil Code by the buyer is necessary to perfect a claim for a non-conforming delivery. ${ }^{56}$ Another section of the Civil Code provides:

In the event of delivery of incomplete products the buyer must require them to be made up or replaced by complete products and refuse to pay for them until so replaced or made up, or, if he has already paid for them, to demand the return of the sums paid.

If the supplier fails to complete the products within the period agreed on by the parties, the buyer is entitled to reject the products. ${ }^{57}$

A classic example of rightful rejection of goods not delivered on time is Moscow Office $v$. Power Institute, ${ }^{58}$ in which the plaintiff delivered an order of pipes three months late, and two months after defendant asked that they not be delivered because he no longer needed them. The decision was for the defendant since he had forewarned the supplier that he would refuse to accept the goods. ${ }^{59}$

State Arbitrazhy have adopted a variation of the requirement of notice by the buyer of refusal to accept or to pay for non-conforming goods, and have allowed a supplier to protect itself against the consequences of an unrealistic delivery order, which is usually not an excuse for non-performance, ${ }^{60}$ by giving notice of its intention to make a nonconforming delivery. ${ }^{61}$

58 "The buyer has the right, on notifying the seller, to reject products which are not delivered on time, unless the contract otherwise provides." R.S.F.S.R. 1964 GrAzH. Kod. (Civil Code) art. 259 (para. 2).

57 R.S.F.S.R. 1964 Graze. Kod. (Civil Code) art. 264 (paras. 2-3).

58 [1958] 8 Sbornik 47 (Collection), in Loeber, stpra note 7, at 160.

50 Where there is no breach by the seller, of course, the buyer cannot refuse to accept goods. In Plant "Prozhektorniye Ugli" v. Kiev Plant, [1958] 8 Sbornik 49 (Collection), in Loeber, supra note 7, at 161, the buyer requested that the seller terminate deliveries because the buyer no longer needed the products. The seller, however, delivered the goods, and State Arbitrazh upheld its claim for payment on the obvious ground that the buyer's refusal to accept was a unilateral act; it is a basic contract principle that contracts cannot be modified by unilateral actions.

60 See, e.g., Suit of Tikhvinsky Aluminum Factory (State Arbitration of the Bryansk Executive Committee 1966), in [1967] 20 Sov. IUST. 32, discussed in text accompanying notes $44-45$ sipra.

61 In Libnekht Plant v. Kuz'min Plant, [1957] 6 Sbornik 40 (Collection), in Loeber, supra note 7, at 153, the supplier was ordered by its superior to deliver more than its program of production called for; the enterprise informed the buyer and the buyer's superior planning agency. Arbitrazh dismissed the buyer's complaint since the producer complied with the applicable regulations on advance notice. The Arbiter mentioned that the buyer's superior could find another supplier, but this case stands for the proposition that, if the contract calls for the delivery of $X$ amount of goods and the plan orders the delivery of $X+1$, the supplier does not have to deliver the extra goods if it gives notice to the buyer, which can make arrangements to get the extra goods elsewhere. The supplier is merely required to perform as promised in the contract. 
Clearly, a seller who tenders a non-conforming delivery but gives no notice to the buyer has no recourse, ${ }^{62}$ unless the "contract otherwise provides." In Leningrad Optical-Mechanical Union v. Gorky Milling Tool Factory, ${ }^{63}$ there was a contract for the delivery of milling tools in 1966, which stipulated that the goods were to be shipped in equal parts per quarter, and monthly within each quarter. At the same time, a provision of the contract allowed the supplier the right of anticipatory shipment of products without the consent of the customer. In fulfilment of the contract, the supplier shipped in July, 1966 , the goods for the fourth quarter of 1966, and demanded payment from the buyer. The buyer refused to pay on the ground that the July delivery was a violation of the provision for equal shipments.

The R.S.F.S.R. State Arbitrazh upheld the claim of the supplier, referring to the provision in the contract dealing with anticipatory shipments. The Chief Arbiter, upon reconsideration of the case, affirmed the result-that the buyer bears the responsibility to accept and to pay for goods shipped early. The establishment in the contract of periods of monthly delivery did not exclude the introduction into the contract of a provision about the anticipatory shipment of goods.

One way the consuming enterprise can protect itself from the seller's charge that delivery was in fulfillment of contractual obligations and that the buyer's refusal to accept or to pay for a non-conforming delivery was a unilateral act is to object before the conclusion of the contract by a "Protocol of Disagreement." 64 Pavlodarsky Tractor Factory v. "Armmashsnabsbita" 65 involved the buyer's refusal to pay for compressors on the ground of incompleteness. The lower arbitrazh awarded the purchase price to the seller, but the Deputy Chief Arbiter of State Arbitrazh of the U.S.S.R. Council of Ministers reversed the decision and denied the factory's claim when it became apparent that, upon entering into the contract, the buyer entered a "Protocol of Disagreement" insisting that the compressors must be complete with receivers. The Pavlodarsky Factory, having received the protocol of the

62 Where 407 tons of pork were delivered ahead of time at the order of the superior of the Azerbaydzhan Office of Meat and Fish Trade Organization (a planning agency), the buyer, a meat combine, was damaged because it had no facilities for cold storage. State Arbitrazh decided for the buyer because the seller did not forewarn the buyer of his intention to make a premature delivery. Baku Meat Combine v. Azerbaydzhan Office of Meat and Fish Trade Administration, [1959] 13 Sbornik 38 (Collection), in Loeber, supra note 7, at 158. See also Izmailovskiy Canned Food Combine v. Ivanovskaya Office, [1958] 8 Sbornik 48 (Collection), in Loeber, supra note 7, at 160-61 (canned vegetables delivered a month late).

63 (State Arbitration of the R.S.F.S.R. Council of Ministers 1966), in [1967] 9 Sov. IUst. 33.

64 See text accompanying notes $28-29$ supra. The buyer may also protect itself by providing in the contract for a reasonable opportunity to inspect the goods for conformity with the contract before acceptance. Cf. UNIFORM COMMERCIAL CoDE $\$ 2-606(1)(a)-(b)$.

65 (State Arbitration of the U.S.S.R. Council of Ministers 1966), in [1967] 15 Sov. IUST. 20. 
buyer in the proper form and not having disputed it, was assumed to have accepted it and to have obliged itself to deliver completed goods. ${ }^{68}$

\section{Substandard Goods}

The R.S.F.S.R. Civil Code of Obligations provides:

In the event of the supply of products of a quality lower than that required by the State standard, approved technical conditions or models, the buyer must reject the products and refuse to pay for them, or, if the buyer has already paid, the sum must be returned to him. ${ }^{67}$

The problem of deliveries of substandard goods is apparently one of great concern among Soviet lawyers and, most likely, Soviet managers. The Chief of the Codification Group of State Arbitrazh of the U.S.S.R. Council of Ministers has stated that fully twenty per cent of the disputes before State Arbitrazh involve the quality of products delivered. ${ }^{68}$ Arbitrazh has recognized, according to him, that delivery contracts should include specifications as to quality, corresponding to the minimum standards set by the appropriate state committee. Evidently the sanctions, if any, involved in the planning procedure are inadequate to influence manufacturers to meet the established stateimposed standards. The application of ordinary contract rights and remedies is suggested. Enterprises are urged not to pay for substandard goods and, if they do, to demand their money back. In addition, state agencies such as banks are encouraged to bring financial influence upon enterprises which ship inferior products. ${ }^{69}$

What is most important is "continuous improvement in the quality of production," which is a "paramount economic-political task." 70 The Soviets evidently feel that enforcement through horizontal contractual rights and obligations will be more effective than sanctions imposed for breach of the vertical duty to perform under the plan. Consequently, the present approach of Arbitrazh is not far removed from the imposition of absolute liability on suppliers of defective or substandard goods. For example, in Chelyabinsk Office of "Rosbakalei" v.

66 A case in which a Protocol of Disagreement probably would not have been very helpful, and in which the buyer should not be entitled to refuse acceptance, is described by Professor Loeber: it was a dispute between two warehouses in which the buyer tried to justify refusal to pay for goods delivered on the ground that there was no longer any public demand for them. Decision was, not surprisingly, for the seller. At the time of the signing of the contract, the goods probably were in demand; it was, evidently, only later that the buyer realized the demand was not as great as it had anticipated. Kostroma Warehouse v. Dnepropetrovsk Warehouse, [1960] 13 Sbornik 41 , in Loeber, supra note 7, at 161 .

67 R.S.F.S.R. 1964 GrazH. Kod. (Civil Code) art. 261.

68 Liberman, supra note 9, at 47.

69 Letter of Instruction of the State Arbitration Agency under the USSR Council of Ministers, March 29, 1962, in Liberman, supra note 9, at 48.

$70 \mathrm{Id}$. at 55 . 
Uvarovsky Sugar Plant, ${ }^{71}$ the plaintiff received shipments of badlycaked sugar. State Arbitrazh established that the caking was the result of failures in the technology of the production process. Defendant argued on appeal that the defects were the result of prolonged storage at the buyer's warehouse and that, in any event, the time for verification of the quality of the sugar by the buyer had expired. Considering itself not at fault in the delivery of the substandard sugar, the defendant requested a change in decision. The Chief Arbiter of the State Arbitrazh of the U.S.S.R. Council of Ministers, on the contrary, established that the sugar was substandard when it was shipped and exacted from the supplier the price of the sugar, as well as a fine for substandard delivery.

It is not always so easy to establish who is responsible for the defective goods. In such a situation, the arbitration agencies are even more likely to hold the immediate supplier absolutely responsible. A Kazan department store received slipcovers produced by a textile plant and shipped in cheesecloth bags which had traces of mold from dampness. The supplier, the Tatar Republic trade base, denied all liability as to quality since it received the slipcovers by water transport from another trade base and forwarded them the very next day by truck to the department store. ${ }^{72}$ State Arbitrazh of the R.S.F.S.R. Council of Ministers awarded damages to the department store, stating that defendant, once it observed that the bags were dirty and torn, was obliged to ship goods of acceptable quality. Since it was impossible to determine where the defects arose-at the manufacturer, at the other trade base or in transport-defendant was held liable. ${ }^{73}$

A dispute reflecting one of the most serious concerns motivating the economic revisions of the last six years ${ }^{74}$ occurred between a Moscow warehouse and a porcelain factory. ${ }^{75}$ The contract between the factory and the warehouse required the delivery of dishes to a number of buyers listed in the warehouse's distribution order (raznaryadok). The factory overfulfilled its plan of production (in number of dishes), but did not fulfill the planned value of the dishes. ${ }^{78}$ In other words, they supplied cheaper dishes. The buyer's suit for damages for in-

71 (State Arbitration of the U.S.S.R. Council of Ministers 1967), in [1967] 18 Sov. IUST. 31.

72 Tatar Trade Base "Rostorgadezhda" v. Kazan Department Store (State Arbitration of the R.S.F.S.R. Council of Ministers 1967), in [1967] 12 Sov. IUsT. 31.

73 See also Trust of Mineral Geology v. "Neftaburmashremont" (State Arbitration of the U.S.S.R. Council of Ministers 1965), in [1966] 6 Sov. IUST. 32 (incomplete drilling rigs shipped by sub-supplier; shipper held liable to purchaser, with suit over against manufacturer).

74 See text accompanying notes 79-148 infra.

75 Moscow Wholesale Warehouse y. Dulevsky Porcelain Plant, [1958] 9 Sbornik 54 (Collection), in Loeber, supra note 7, at 153-54.

76 The supplier delivered dishes with a value of $48,000,000$ (pre-1961) rubles, about $\$ 5,200,0000$, whereas the distribution order called for the production of $55,000,000$ (pre-1961) rubles, about $\$ 6,050,000$, worth of dishes. 
complete delivery was dismissed since the factory fulfilled its production plan! ${ }^{77}$

What the arbitrazh ignored was that the factory only fulfilled part of its plan-the number of dishes to be produced-but failed to fulfill the planned value of the order. The case, decided ten years ago, indicates an obsession with output rather than sales. The plan called for so many dishes, and the factory produced that many plus almost six per cent more. ${ }^{78}$ It was not important to the producer that the dishes shipped were not the ones ordered, or of the wrong price, because the manager knew that the dishes could be sold in any event. The obvious inference from this decision is that the buyer had to pay no more than forty-eight million rubles, the value of the dishes shipped. But why should he not be entitled to damages as well, especially if one of the warehouse's customers refused to pay for the dishes because they are not those ordered?

\section{The New Economic Management: A Dialogue}

As it celebrates its fiftieth anniversary, ${ }^{79}$ the Soviet Union is implementing a number of proposed changes in its economic system in order to stimulate efficient production and improve the quality of consumer goods and of manufacturing generally. These changes will affect the functions of Arbitrazh within the system; to discover the role of the law of State Arbitrazh in this new order, let us imagine the following dialogue between the first Chief Arbiter of State Arbitrazh of the U.S.S.R. Council of Ministers-an old Bolshevik-and Premier Alexei Kosygin.

Arbiter: The history of contracts and arbitration boards in the Soviet Union was intertwined with the administration of the economy in the first decade and a half of Bolshevik rule. Arbitration commissions were first created in $1922^{80}$ to operate certain expropriated industries. Several years later, a Supreme Arbitration Commission of the U.S.S.R. was established to hear disputes of an all-union nature. ${ }^{81}$ All along, the emphasis was on wise administrative decisions rather than on the consistent application of the law of obligations. ${ }^{82}$

77 See text accompanying notes 146-47 infra for a discussion of how this case would be decided today.

78 High over-production is quite unusual because, under the so-called "ratchet" principle, the next year's delivery order would be geared to the higher figure. In other words, the manager tries to overfulfill his target, but not by too much. As Professor Nove put it, writing before the reform, "a wise director fulfills the plan 105 per cent, not 125 per cent." Nove, The Problem of "Success Indicators" in the Soviet Industry, in READINGS oN THE SovieT Economy 433, 436 (F. Holzman ed. 1963). Iution!

$7 \theta$ Hail to the glorious Fiftieth Anniversary of the Great October Socialist Revo-

80 Decree of Sept. 21, 1922, [1922] 1 Sob. Zak. S.S.S.R. No. 60, Item 769 (Collection of Laws of the U.S.S.R.).

81 Decree of May 6, 1924, [1924] 1 Sob. Zak. S.S.S.R. No. 62, Item 618 (Co1lection of Laws of the U.S.S.R.).

82 Hazard, Flexibility of Law in Soviet State Arbitration, in INTERNATronal Arbitration 120, 122-23 (P. Sanders ed. 1967). 
The existence of arbitration commissions ping-ponged during the period of the first "Five-Year Plan." ${ }^{83}$ An arbitration department was created by the Supreme Council of National Economy (under the U.S.S.R. Council of Ministers) for the adjudication of disputes between state enterprises. ${ }^{84}$ Two weeks after its creation, this department was abolished by the decree of March 4, 1931, returning the jurisdiction of all such disputes to the court; ${ }^{85}$ two months later, the policy was again reversed and the administrative department of State Arbitrazh was re-established. ${ }^{86}$ The operation of Arbitrazh then continued throughout the period of the five-year plans.

Kosygin: Allow me to update this discussion by describing the new economic system announced in $1965,{ }^{87}$ and then perhaps you would

83 The following approximately indicates the initial periods of Soviet economic development and the concomitant role of contracts and arbitration commissions.

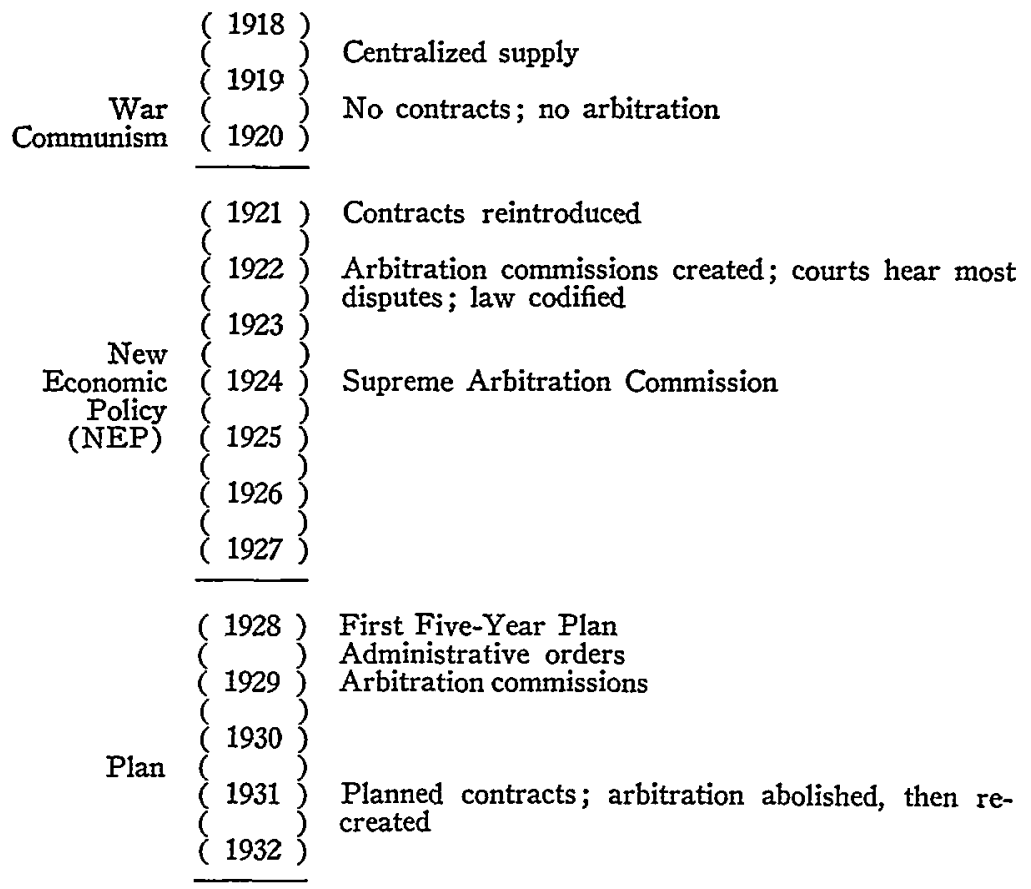

84 Decree of Feb. 18, 1931, [1931] 1 Sob. Zak. S.S.S.R. No. 10, Item 109 (Collection of Laws of the U.S.S.R.), in HAzARD \& SHAPIRo 98.

85 Decree of March 4, 1931, [1931] 1 Sob. Zak. S.S.S.R. No. 14, Item 135 (Collection of Laws of the U.S.S.R.), in HAZARD \& SHAPIRO 98.

80 Decree of May 3, 1931, [1931] 1 Sob. Zak. S.S.S.R. No. 26, Item 203 (Collection of Laws of the U.S.S.R.), in HAZARD \& SHAPIRO 98 . Hazard and Shapiro describe this period simply as "chaos." Id.

87 The touchstone of the reform movement is Premier Kosygin's Report to the Plenary Session of the Central Committee of the Communist Party of the Soviet Union in September, 1965, Pravda, Sept. 28, 1965, translated in 17 CURRENT Digest of the Soviet PRESS No. 38, at 3 (1965). 
tell me how you think the law of Arbitrazh-and indeed, the system of arbitral tribunals-is affected.

The essence of the reform is the shift of a considerable amount of decision-making from planning agencies to the enterprises themselves. The principle of central planning, however, has been retained by placing the enterprises under the control of industrial ministries, thus eliminating much of the overlap of planning organs. ${ }^{88}$

The prime change of emphasis for the individual enterprise is that the incentive to fulfill the planned tasks is now related to volume of sales; the manager of an enterprise can no longer be satisfied with fulfilling or overfulfilling a plan of physical output, since as a seller, he gets no credit for output until the goods are sold. In 1962, Professor Liberman of Kharkov University officially formulated his proposal that the main criterion of success of an enterprise's operation should be its volume of sales. ${ }^{89}$ In accordance with this suggestion, the long, detailed list of planned "indicators" has been reduced considerably, and the enlarged powers of the managers have been specified in a new Statute for State Enterprises. ${ }^{00}$

Arbiter: I know that the reforms have been widespread ${ }^{91}$ and

88 The first important change made in the structure of the Soviet economy was the abolition of the regional economic councils (somarkhozy), which were established in 1957. For a description of the shortcomings of the sovnarkhoz system, see H. Schwartz, The Soviet Economy Since Stalin 148-58 (1965). A general law on the organization and operation of the Ministries was enacted in 1967. General Statute on USSR Ministries, Decree of July 10, 1967, No. 640, Ekonomicheskaya Gazeta, Aug. 22, 1967, at 7,6 Sov. L. \& Gov't No.2, at 3 (1967), 19 CURRENT DigesT OF THE SOVIET PRESS No. 37, at 3 (1967).

80 Pravda, Sept. 9, 1962, translated in 14 CuRrent Digest of the Soviet Press No. 36, at 13 (1962), reprinted with some omissions as Liberman, The Plan, Profits and Bonuses, in THE SovIEx Economy 352-58 (M. Bornstein \& D. Fusfeld eds. 1966). Professor Nove has summarized the terms of the proposals, not all of which were adopted by the September 1965 Plenum, in Nove, Revamping the Economy, 12 ProsLeMs of CoMIMUNisM No. 1 , at 10, 13 (1963).

One observer has claimed that the most significant aspect of the Liberman proposals is that they aroused unreserved criticism of long-standing policies and theories, and heated debate over the advisability of a revision of the planning methods. Shaffer, $A$ New Incentive for Soviet Managers, 22 Russian Rev. 410, 416 (1963).

80 Statute on the Socialist State Production Enterprise (U.S.S.R. Council of Ministers 1965), Ekonomicheskaya Gazeta, Oct. 20, 1965, at 25, 2 Sov. STAT. \& Dec. No. 3, at 52 (1966), 17 Current Digest of the Soviet Press No. 42, at 3 (1965), Joint Publications Researce Service, U.S. Dep't of Commerce (Pub. No. 32,685, 1965). The spirit of the reforms pervades the statute. Article 29 reflects the major change in production activities of state enterprises; it seeks to prevent the manufacture of unwanted goods by two devices: making non-fulfillment of delivery plans a gross violation of state discipline, and prohibiting production above the planned level unless arrangements have been made for the disposal of the goods.

The rights of state enterprises have been expanded to include the rights: (1) to establish direct economic links between supplier and consumer [art. 30]; (2) to prevent orders that are impossible to fulfill, to require mutually consistent planned assignments, and to require that superior organs guarantee the necessary fondy [art. 46]; (3) to prevent plan changes unless there is a full adjustment of all contractual relations involved [art. 47]; and (4) to refuse excess or unnecessary products upon timely notice [art. 62]. See Maggs, Soviet Corporation Laze: The Neze Statute on the Socialist State Production Enterprise, 14 AM. J. Comp. L. 478 (1965).

91 Professor Liberman, in an article written for western consumption, reported at the end of the first quarter of 1967 that "more than 2,200 enterprises, including almost 
eminently successful, ${ }^{92}$ but for my purposes I should like to find out whether stress is now placed on direct contracts between enterprises, rather than on obligatory contracts entered into under a plan.

Kosygin: Considerable stress is placed on direct contracting, in order to allow managers to use resources with maximum effectiveness and to free planners from the tasks of issuing complex commands.

Arbiter: This is precisely what I expected. The history I described has shown that when civil law contracts predominated, the courts usually had jurisdiction of disputes in accordance with the civil law principles of obligations. ${ }^{93}$ Are you suggesting that the arbitration tribunals will again be abolished, as they were in 1931? ${ }^{94}$ After all, the distinction between the administrative arbitration tribunals and the ordinary judicial courts is becoming slight.

Kosygin: I definitely do not foresee the abolition of the structure of State Arbitrazh, leaving all disputes between state enterprises to the competence of the People's Courts. But there is a marked trend toward stability, both in the law applied by State Arbitrazh and in the arbitration process itself. ${ }^{95}$ As the American Professor Hazard has said, "[T]he arbitration tribunals have been moving away from the position given them when they were brought into being in their present form in 1931 . . . They have come nearer to the position of a court

all the instrument manufacturing plants, many light-industry factories and mills, and ferrous and nonferrous metallurgical plants are.. operating under the new system ..." Liberman, The Soviet Economic Reform, 46 FoREIGN AFFAIRS 54, 56 (1967). It is not known, however, what percentage of the total output of the Soviet Union these 2,200 plants represent. The official summary of statistics reports that by the end of the first quarter of 1968, "there have been converted to the new system of planning and economic incentive about 10,000 industrial enterprises, comprising almost one-half of all industrial production." After listing the ministries in which all of the enterprises are under the new system, the summary concludes that all enterprises under the new conditions overfulfilled the plan for the first quarter of 1958 , both as to production and as to profit. Pravda, Apr. 18, 1968, at 2.

92 But see the conclusion that "In terms of announced Soviet intentions, the reform was a modest success." Frankel, Economic Reform: A Tentative Appraisal, 16 ProBLEMS OF COMMUNISA No. 3, at 29,41 (1967) (emphasis added). Apparently, the pioneer plants on the new system were all unusually high in profitability before the change. Bush, The Reforms: A Balance Sheet, 16 Problems of Comarunism No. 4, at $30,32(1967)$.

93 See note 83 supra.

94 See text accompanying notes 79-86 supra. The Bolshevik's concern is justified, since he has read about the characteristics of State Arbitrazh in 1931, described by the American Sovietologists, Hazard and Shapiro, as follows: (1) judges specializing in relationships of public corporations; (2) performance of the plan as the ultimate object of the administration of rules; (3) directors of corporations and professional arbitrators to participate-no legal advisers [jurisconsults]; and (4) damages and penalties a secondary concern. HAzARD \& SHAPIRo 98.

Of these concerns, only the last assumes considerable importance under the new system of economic management. Under a system which emphasizes the civil law of obligations, there is no need for judges specializing in the law of state corporations; the "performance of the plan" is no longer the polestar in the administration of the Soviet economy; and there is certainly an increased role for jurisconsults in the arbitration process.

95 Hazard, supra note 81, at 126. 
charged with the protection of 'rights' through the stable application of law." ${ }^{9 B}$ There are several themes of the reform that must be carried out, all leading to the stabilization of law and procedure of Soviet State Arbitrazh.

First, recentralization of the arbitration structure. In the spirit of the September 1965 Plenum, the organs of Soviet State Arbitrazh must be centralized. Since 1931, the system has been without vertical subordination of arbitration tribunals, and superior arbitrazhy have not had the power to review the decisions of lower agencies in matters relating to the competency of the latter. ${ }^{97}$ Under the discarded sovnarkhoz system, ${ }^{98}$ each economic council issued its own rules on arbitration, giving rise to many claims and manifestations of localism, especially, it seems, in disputes involving the delivery of meat and livestock.$^{99}$ Many of these rules are still operative.

This is intolerable. A single set of rules and regulations must be published to ensure that the union and republican tribunals are subordinated to the central arbitral boards so that arbitration practice is uniform. ${ }^{100}$ The higher arbitrazhy should check the activities of the lower agencies and appoint their Chief Arbiters. ${ }^{101}$

The suggestion has been voiced that it would be expedient to transfer review of the legality of decisions handed down by local arbitrazhy to the republican state arbitration tribunals. ${ }^{102}$ The increase in the volume of cases of the republican arbitrazhy would be compensated for by a broadening of the jurisdiction of the local tribunals,

96 Id. at 129-30.

97 Gavrilenko \& Pobirchenko, Strukinru gosudarstvennovo arbitrazha na yroven" zadach novoy khozyaistvennoy reformy (Bringing up the Structure of State Arbitration to the Level of the Tasks of the New Economic Reform), [1966] 6 Sov. Gos. I Prav. 45.

98 See note 88 supra.

99 In a typical case, the defense to a suit for failure to deliver meat was that the seller's supplier did not fulfill his plan of delivering cattle. Plaintiff's suit was upheld when it became evident that defendant had adequate supplies but preferred to deliver the meat for local needs first. Kirgiz Office of the Chief Meat and Fish Trade Administration v. Frunze Meat Combine, [1958] 8 Sbornik 40 (Collection), in Loeber, supra note 7, at 149. See also Semipalatinsk Office of "Skotoimport" v. Semipalatinsk Meat Combine, [1963] 21 Sbornik 101 (Collection), in 2 Sov. STat. \& DEc. No. 3, at 31 (1966), Loeber, supra note 7, at 153; Kirov Meatpacking Plant v. Volhniya Regional Office, [1962] 19-20 Sbornik 35 (Collection), in 2 Sov. Srat. \& Dec. No. 3, at 29 (1966).

100 Ironically, a call for the elimination of dual subordination in State Arbitrazh was made by the Soviets in 1958, immediately after the adoption of the sovnarkhozy. Sadovsky \& Feofanov, Is This What Arbitration Should be Like?, Izvestia, Aug. 21, 1958, translated in 10 CuRrent Digest of THE Soviet Press No. 34, at 21 (1958). The problem was also noted as early as 1961 by a British lawyer who visited the Soviet Union. Johnson, Planning and Contract Law, 12 Sov. Studres 263, 264 n.11 (1961).

101 Ordynsky, Problems in the Work of State Arbitration Agencies anter the New Industrial Management Conditions, [1966] 5 Sov. Iusr. 4, translated in JorNT Publications Research Service, U.S. Dep't of Commerce, Translations on SovieT Law and Social Regulations 6-7 (Pub. No. 37,626, 1966).

102 Geshlina, Nyekotoriye normy polozheniy o gosarbitrazha nyzhdayutsa v izmenyeniy (Some Provisions of the Statute on State Arbitration Must be Revised), [1966] 12 Sov. Gos. I Prav. 71, 73. 
for example, by raising their jurisdictional maximum amount to 7,000 rubles in contract disputes and to 700,000 rubles in pre-contract cases. ${ }^{103}$

Second, courts of conciliation. In light of the possibility of an increased workload for local arbitrazhy, we must turn our attention to an alternate means of settling disputes between state enterprises. Arbitrazh is an administrative court, specializing in economic disputes; it is not a conciliation agency in the western sense of "arbitration," that is, a procedure for effecting compromises between the parties. There are such conciliation courts in the Soviet Union, known as treteiskiye sudy, and they derive their competence from section 4 of the Statute on State Arbitration of the U.S.S.R. Council of Ministers, which provides that "Individual economic disputes may, by mutual consent of the parties, ${ }^{104}$ be transferred for resolution by a court of conciliation chosen by the parties to consider the case." ${ }^{105}$ The operation of the conciliation courts is governed by Temporary Rules; ${ }^{106}$ they are competent to consider any dispute which is within the jurisdiction of State Arbitrazh.

Although it has already been eight years since the promulgation of the Temporary Rules, conciliation courts have not been widely utilized. Enterprises rarely resort to them, ${ }^{107}$ and one reason for this is the cumbersome procedure established by the Rules for the election of these courts. ${ }^{108}$ Therefore, it would be advisable to establish a public institute of courts of conciliation for local councils, which would make recommendations for the composition of the courts from a panel of economists and technocrats.

The Temporary Rules should be amended to stipulate the obligation of local economic enterprises to transfer disputes for resolution by the courts of conciliation; arbitrazhy in such situations should not accept such suits. ${ }^{109}$ In addition, state arbitration agencies must give

103 Id.

104 If the defendant does not reply to the request to transfer a case to a court of conciliation or to choose a judge, the decision of the conciliation agency lacks legal force; such a dispute may only be heard by a state Arbitrazh. Perevoz District Industrial Combine v. Construction Unit of Arzamas Building Trust No. 7, [1962] 18 Sbornik 48 (Collection), in 2 Sov. STAT. \& Dec. No. 1, at 69 (1965).

105 Statute on State Arbitration of the U.S.S.R. Council of Ministers \$4, [1961] Zak. Akty 745 (Legislative Acts 1960), 2 Sov. Stat. \& Dec. No. 1, at 5 (1965), Hazard \& Shapiro 113-16, 12 Current Digest of the Soviet Press No. 42, at 15 (1960).

106 Temporary Rules of Consideration of Economic Disputes by a Court of Conciliation [and Instructions in connection therewith] [1964] Instr. Ukaz. 60 (Directive Instructions 1960), 2 Sov. STAT. \& DEC. No. 1, at 57 (1965). The purpose of the courts of conciliation is to develop "democratic forms of resolution of economic disputes," rather than to rely on the compulsory implementation of arbitration orders. Temporary Rules $\$ 1$.

107 See Letter of Instruction of July 20, 1961, [1962] 18 Sbornik 17 (Collection), 2 Sov. StaT. \& DEC. No. 1, at 64 (1965).

108 Yershov, $O$ Praktike gorkovskovo gosarbitrazha po primenyeniyou novykh pravil rassmatreniya xozyaistvennykh sporov gostdarstvennymi arbitrazhami (On the Practive of the Gorky State Arbitrazh concerning the Application of the New Regulations on the Settlement of Disputes arising in the Sphere of National Economy by State Arbitration Tribunals), [1966] 2 Sov. Gos. I PrAv. 87.

109 See id. 
active support to the courts of conciliation, assist them in transferring disputes, and bring the Temporary Rules to the attention of the parties. ${ }^{110}$

Third, compulsory implementation. In effectuating the rapid resolution of pre- and post-contract disputes, Arbitrazh relies, in the first instance, upon the voluntary implementation by the parties of an arbitration decision. ${ }^{111}$ However, there is also provision for mandatory execution of the decision following the lapse of a specified time. ${ }^{112}$ The distressingly large number of such compulsory orders indicates that the principle of voluntary compliance must be reworked. An amendment to the Statute on State Arbitration has been proposed to introduce a general procedure whereby a compulsory order would be issued simultaneously with decision. ${ }^{113}$ Arbitrazh would establish a period for the voluntary fulfillment of the decision if, according to the nature of the decision, it could not be fulfilled quickly, or if defendant should petition for the period. ${ }^{114}$ This would eliminate the undesirable consequences of red tape and delay in the receipt of funds and the mistaken payment of fines.

Fourth, pre-contract disputes. The rapid resolution of precontract disputes is vital to the essence of the reforms-increased independent decision-making by enterprise directors. Since the range of indicators to the managers is considerably diminished, the enterprise now fulfills its production plan on the basis of completed contracts; contract terms such as quantity, quality, assortment and order of delivery have replaced many of the commanded indicators of superiors. Perhaps disputes over such terms are not legal in nature and can best be resolved by the superior agencies of the contracting partners. But the transfer of such disputes to the higher agencies would fly in the face of the spirit of the reform, which seeks to maximize non-interference of planning agencies in the activities of economic enterprises.

In this context, Comrade Kleyn, a member of the All-Union Scientific Research Institute of Soviet Legislation, has made a startling proposal: that enterprises must be allowed to challenge orders of an

110 A letter from the State Arbitrazh of the U.S.S.R. Council of Ministers describes the "significant assistance" that the arbitrazh of the Moscow Regional Executive Committee rendered by conducting a conference on the courts of conciliation. Letter of Instruction of Nov. 28, 1961, [1962] 19-20 Sbornik 4 (Collection), 2 Sov. Stat. \& DeC. No. 1, at 66 (1965).

111 Statute on State Arbitration of the U.S.S.R. Council of Ministers $\$ 12$ (para. 1), [1961] Zak. Akty 745 (Legislative Acts 1960), 2 Sov. Stat. \& Dec. No. 1, at 5 (1965), Hazard \& Shapiro 113-16, 12 Current Digest of the Soviet Press, No. 42, at $15(1960)$.

112 Id. $\$ 12$ (para. 2). But see the procedure in the courts of conciliation, which requires the mutual consent of the parties, described in the text accompanying notes 104-110 supra. Under the present arbitration statute, such a procedure is envisioned under exceptional circumstances.

113 Id. at $\$ 12$ (para. 3).

114 Geshlina, supra note 102 , at 72. 
economic management agency by way of State Arbitraah. ${ }^{115}$ It is presently impossible for an enterprise to "sue" its superior in Arbitrazh to rescind an unrealistic delivery order or to recover damages for failure to supply it with the necessary raw materials to fulfill its contractual obligations, ${ }^{116}$ even though the shortcomings of the superior may be attributed to the enterprise. ${ }^{117}$ Enterprises were virtually compelled to undertake contractual obligations that were impossible to fulfill. Comrade Kleyn argues that ever since enterprises were granted the right to refuse to conclude contracts for the delivery of unwanted goods, ${ }^{118}$ State Arbitrazh has had a right to refuse to compel them to enter into contracts that do not correspond to their economic activity. ${ }^{118}$ It has been asserted that " $[\mathrm{c}]$ hanges in the administrative and planning system make it necessary to create new legal norms, which protect the enterprise against the presently existing unlawful intervention of higher agencies within its competence." 120

There are indications that this change in the jurisdiction of State Arbitrazh may already be taking place. One such indication was a suit by the Moscow Central Knitting Base, a planning agency, to require the Kosinsk Knitting Plant, its subordinate, to conclude an additional contract for the delivery of knitted goods based on a change of the planning act. Since the plant was operating under the new economic management, and the superior neither provided the plant with the additional raw materials nor made changes in inter-related plans, State Arbitrazh of the R.S.F.S.R. Council of Ministers refused to order the consummation of the contract. ${ }^{121}$

An arbitrazh, it is argued, is the best agency for determining the legality of a planning order because it is a disinterested organ with an established fact-finding apparatus. In addition, Arbitrazh can apply an effective sanction by revoking the "illegal" order involved. ${ }^{122}$

This proposition apparently has the approval of a majority in the Institute of Government and Law of the Academy of Sciences of the

115 Kleyn, Arbitration and the Consolidation of Legality in the National Economy, [1967] 8 Sov. Gos. I Prav. 51, translated in Joint Publications Research Service, U.S. DEP'T OF COMMERCE, USSR ECONOMY AND INDUSTRY, GENERAL INFORMATION 1, 12 (PUB. No. 42,813, 1967).

116 See text accompanying notes $47-49$ supra.

117 See text accompanying notes $39-45$ supra.

118 See note 90 supra.

119 Kleyn, supra note 115 , at 7-8.

120 Id. at 10 (emphasis added). "The arbitration practice of recent years, as a rule, does not attribute legal significance to changes in production plans, if the changes were not coordinated with the trading organizations, or if a plan was changed despite the objections of the trading organizations." Id. at 8. See, e.g., Novo-Kramatorskiy Machine Building Plant v. Izhorskiy Plant, [1957] 6 Sbornik 38 (Collection), in Loeber, supra note 7, at 157; Warehouse in Latvian SSSR v. Penza Warehouse, [1960] 14 Sbornik 58 (Collection), in Loeber, supra note 7, at 156, discussed in the text accompanying notes 50-55 supra.

121 Kleyn, supra note 115 , at 11.

122 Id. at 13-14. 
U.S.S.R.; ${ }^{123}$ to doubt the expediency of the suggestion, according to the Institute, would be to nullify the independence of the contracting enterprises in the resolution of important economic disputes. ${ }^{124}$ Provision, therefore, must be made to stabilize the procedure for an enterprise to "bring suit" in State Arbitrazh against its superior to determine the appropriateness and legality of a planning order. Thus, an entirely new perspective is introduced into the role of State Arbitrazh: the obligation to oversee the process of plan implementation not only by resolving contract disputes between operating enterprises, but also by intervening in the vertical relationship between an inferior enterprise and its planning superior.

Fifth, the concept of fault. The increased role of Arbitrazh in settling administrative ${ }^{125}$ disputes introduces the most perplexing dilemma now facing us-whether the only basis of contractual liability of an enterprise should be fault. The matter would seem to have been disposed of by article 37 of the Fundamentals of Civil Legislation of the U.S.S.R., which reads:

A person who fails to perform an obligation or performs it improperly incurs material liability for damages . . . only in the presence of fault (intentional or negligent) except in cases provided by law or contract. ${ }^{126}$

The meaningful question, however, is which "person" must be at fault. The doctrine of attribution of fault ${ }^{127}$ has been used by Arbitrazh when it could not be shown that the manager or workers of an enterprise were actually to blame for non-delivery; the enterprise, as a legal "person," was held responsible, even though (due to the complication of economic ties) the "guilty" party was a co-operating enterprise, perhaps far along the chain of suppliers, or the enterprise's superior planning agency.

One solution is to grant State Arbitrazh the power to discipline officials of enterprises guilty of violations of contractual obligations, ${ }^{128}$

123 The proceedings of a Conference of the Institute in December, 1966, at which time State Arbitration was discussed, are reported in Obsizhdeniye pravovykh voprosof ekonomicheskoy reformy (Discussion of Legal Questions of the Economic Reform), [1967] 4 Sov. Gos. I Prav. 132, 135.

124 Id.

125 See note 48 supra and accompanying text.

126 Fundamentals of Civil Legislation of the U.S.S.R. art. 37, [1961] Ved. Verkh. Sov. S.S.S.R. No. 50, Item 525 (Sup. Sov. U.S.S.R. 1961). The Fundamentals (or Principles) were adopted by the Supreme Soviet of the U.S.S.R. and served as the basis for the civil codes of the union republics. See, e.g., R.S.F.S.R. 1964 GRAzE. Kod. (Civil Code) art. 222.

Translations of the Fundamentals appear in in Soviet Crvil Legislation AND Procedure 55-114 (1963), 14 CURRent Digest of THE Soviet Press No. 4, at 3 (1962), and 3 Sov. REv. No. 5, at 22 (1962), 3 Sov. REv. No. 6, at 50 (1962), 3 Sov. REv. No. 7, at 26 (1962), 3 Sov. Rev. No. 8, at 41 (1962).

127 See text accompanying notes $39-45$ supra.

128 See note 9 supra. 
and, also, to discipline employees of economic planning organs who approve unrealistic plans of production. ${ }^{129}$ But it is more desirable to reorganize Gosarbitrazh into a "contract court" which will enhance the role of the contract and have the desirable added consequence of stabilizing the substantive provisions on liability. ${ }^{130}$

The commentators who call for rigid adherence to the principle of fault as the basis of contractual responsibility ${ }^{131}$ would presumably enhance the concept of fictitious fault, freeing State Arbitrazh from any responsibility for investigating the underlying reasons for non-conforming deliveries. ${ }^{132}$ In accordance with a decision to allow Arbitrazhy to consider challenges to the legality of planning orders, ${ }^{133}$ liability should be imposed on the joint entity of the enterprise and its superior. However, the operating plant should now be free to recover from its superior agency any damages or fines exacted, if it can be shown that the enterprise, at an early stage, challenged the appropriateness of the planning order which induced it to breach a contractual obligation.

In the case of a defaulting supplier in another ministerial or departmental hierarchy, a defendant should be entitled to implead the supplier in the original Arbitrazh suit. ${ }^{134}$ When considering such suits for breach of contract, Arbitrazh should require defendant to have taken ordinary measures to obtain materials or funds elsewhere before it will allow a reduction of liability in accordance with the amount of materials that the impleaded defendant failed to produce or ship as required in the contract. In addition, the impleaded defendant should pay to the prime defendant damages including not only the fine, but also indirect losses such as lost profits. ${ }^{135}$

In short, in a suit by a buyer against a defaulting seller, State Arbitrazh should broadly construe the statutory term "person" to include both the enterprise and its superiors. In subsequent claims by the seller against the defaulting suppliers or superiors, the concept of

129 Rabinovich, Vina kak osnovaniye dogovornoy otvetsvennosti sotsialisticheskovo predpriyatiya (Fault as the Basis of Contractual Liability of a Socialist Enterprise), [1966] 6 Sov. Gos. I Prav. 30, 37. The author is the State Arbiter of the Moscow City Executive Committee Arbitrazh.

130 See notes 95-96 sipra and accompanying text.

131 See, e.g., Rabinovich, sipra note 129.

132 It should be impossible, Rabinovich maintains, to prove fault of an enterprise in the absence of fault of its managers. Id. at 32 .

133 See text accompanying notes 115-24 sipra.

134 There are three prototype disputes arising now, each of which demands a different solution. The first situation is a dispute between two enterprises, both of which are still planned as before. There is no reason to remove such disputes from the competency of State Arbitration. The second and third situations involve enterprises on the profit system. A dispute between two enterprises operating under the new incentive arrangement, or a disagreement between one enterprise which operates under the reforms and one which operates under the planned method might necessitate some collegium or combination of the Arbitration panel and experts of the law of obligations, perhaps civil judges or the foremost leaders of industry. In the latter situations, it is desirable to have both an expert in the law of the planned economy and an expert in the civil law of obligations.

135 Sikirin \& Falkovich, The Principle: Mutual Responsibility, abstracted in 18 Current Digest of THe Soviet Press, No. 12-II, at 4 (1966). 
"fault" should be narrowly interpreted to impose an ordinary reasonableness standard on the part of the managers of enterprises and their responsible officials. ${ }^{136}$

Sixth, the wholesale price structure. A task of the reform of economic management is to ensure the profitability of every operating enterprise. ${ }^{137}$ The profitability of an enterprise is based, to a great extent, on the price at which it can sell its output. The economic managers realized that the fixed-price structure in the Soviet Union was far from being rational. The first price revisions went into effect in October, 1966, and by July, 1967, the entire system was revised.138 Now that the price of a product is an important condition of the delivery contract, it is incumbent to reexamine the arbitration practice in price disputes.

Under the present law, state arbitration tribunals cannot consider "disputes over the establishment of prices for products subject to delivery" if the prices are set by actual legislation. ${ }^{139}$ What this means is that every contract must make specific mention of the price of the product by reference to an official price list, and Arbitrazh has the power to invalidate contracts that specify prices in violation of the fixed prices. ${ }^{140}$ If there is no established price, contracts are not always voided; Arbitrazh may suspend the consideration of the dispute and request a determination of the applicable price by the appropriate superior planning organ. ${ }^{141}$

A major breakthrough came when managers of supplier-enterprises were granted the right, under certain circumstances, to establish the price of goods with the agreement of the buyer. ${ }^{142}$ The logic of the

136 This decision is compelled by a reading of the "Rights of the Socialist Enterprise": "Rights belonging to an enterprise that are connected with its production and economic activity shall be exercised by the director (manager, chief) and ... by other officials of the enterprise ...." Statute on the Socialist State Production Enterprise $\$ 41$ (U.S.S.R. Council of Ministers 1965), Ekonomicheskaya Gazeta, Oct. 20, 1965, at 25, 2 Sov. Stat. \& Dec. No. 3, at 52 (1966), 17 Curent Digest of the Soviet Press No. 42, at 3 (1965), Joint Publications Research Service, U.S. Dep't of Comarerce (Pub. No. 32,685, 1965). If the rights are to be exercised by the managers, they should bear the responsibility for breaches of obligations.

137 Yakovets, Price and the Reform, Sovetskaya Rossiya, Aug. 11, 1967, translated in JoInt Publications Research Service, U.S. DeP'T of ComMierce, USSR ECONOMY aNd IndUSTRY, GeNeral Information 8, 10 (Pub. No. 42,527, 1967).

$138 \mathrm{Id}$. at. 9. The tendency was for prices of heavy industrial materials to rise approximately $15 \%$; the prices of natural raw materials increased considerably more. Id.

139 Statute on State Arbitration of the U.S.S.R. Council of Ministers $\$ 15(\mathrm{f})$ [1961] Zak. Akty 745 (Legislative Acts 1960), 2 Sov. Stat. \& Dec. No. 1, at 5 (1965), Hazard \& ShapIro 113-16, 12 Current Digest of the Soviet Press No. 42, at 15 (1960).

140 Letter of Instruction of April 28, 1967 (State Arbitration of the U.S.S.R. Council of Ministers), [1967] 9 Sots. ZAK. 89.

141 Johnson, Planning and Contract Law, 12 Sov. Stuntes 263, 269 (1961).

142 Statute on the Socialist State Production Enterprise $\$ 74$ (U.S.S.R. Council of Ministers 1965), Ekonomicheskaya Gazeta, Oct. 20, 1965, at 25, 2 Sov. STat. \& Dec. No. 3, at 52 (1966), 17 Current Digest of The Soviet Press No. 42, at 3 (1965), Jonnt Publications Research Service, U.S. Dep't of Cominerce (Pub. No. 32,685, 1965). 
new economic management compels the conclusion that arbitration tribunals should be allowed to adjudicate disputes over the establishment of such prices. State Arbitrazh always has been competent to resolve disputes concerning prices. It has determined the price of goods when the official price was changed subsequent to the consummation of the contract; it has entertained ${ }^{143}$ a suit by a seller who mistakenly charged less than the established price; ${ }^{144}$ and it has considered a case where a buyer mistakenly paid for a product for which there was no established price. ${ }^{145}$ Thus, it was not that the arbitration boards lacked the expertise, but that the political leaders-rightfully so, for a time-used the wholesale price structure to manipulate the consumer and producer economy by artifically raising and lowering prices. Now that this element of interference has been largely eliminated, the arbitration tribunals may operate to maintain legality in the economic sphere of prices.

Arbiter: Comrade Premier, I still do not understand how all these changes would affect the substantive law of contract which Arbitrazh applies.

Kosygin: Take a case like Moscow Wholesale Warehouse $v$. Dulevskiy Porcelain Plant, ${ }^{146}$ in which a distribution order was held void, and the defense that the supplier fulfilled its plan was allowed to defeat a claim for damages for an incomplete delivery of dishes.

If the supplying factory were operating under the new economic management, the fact that it over-fulfilled its plan of production in number of dishes would be meaningless. There is no longer any independent significance to satisfying part of a production plan, such as the number of dishes, without complying with contractual obligations based on another aspect of the production plan (the value of the goods produced) ${ }^{147}$

143 In this situation, the price in effect at the time of shipment by the seller prevails. Shippers are obliged to immediately inform the buyers about changes of prices for the products. Letter of Instruction of April 28, 1967 (State Arbitration of the U.S.S.R. Council of Ministers), [1967] 9 SoTS. ZAK. 89, 90; Johnson, supra note 141, at 268.

144 State Arbitrazh allows a seller's claim in full. Departmental arbitration, on the other hand, imposes a "joint liability," granting the seller one-half of the difference between the established price and the invoiced price. Johnson, supra note 141, at 268-69.

145 The buyer has the right to demand from the seller the return of the mistakenly paid sum if the goods have not been used. Upon the unfounded refusal of this demand, the buyer may bring suit in Arbitrazh, which must consider the merits of the case. Letter of Instruction of April 28, 1967 (State Arbitration of the U.S.S.R. Council of Ministers), [1967] 9 Sots. ZaK. 89, 90.

146 [1958] 9 Sbornik 54 (Collection), in Loeber, supra note 7, at 153-54. See text accompanying notes 74-78 supra.

147 In fact, overfulfillment of an industrial target may mean greater losses to the state because related organizations, still operating according to plan, must strain to supply raw materials to the over-fulfilling plant, or to absorb its increased production. See Bush, supra, note 91 , at 35 . The economic reform anticipates precise performance. 
The defense that a supplier fulfilled its delivery plan should not be sufficient to defeat a contract claim unless the defaulting enterprise still operates on the output plan. This is so because the responsibility of the enterprise which is in breach of a contractual obligation should be judged according to the system in which its performance, in terms of bonuses and penalties, ultimately will be evaluated.

Arbiter: I take it the result in the Moscow Woolen case ${ }^{148}$-that a producer is liable even if not supplied with sufficient raw materialsis not so harsh if the producer was operating in a profitability system. It is the producer's responsibility to see that it is supplied with adequate raw materials or the funds to obtain them.

Kosygin: Yes, that is so. In conclusion, may I say that the trend toward stabilization of the law applied by State Arbitrazh must be implemented by the proposals put forth here in the spirit of the new economic reform. Arbitrazh, as a specialized economic court, must be concerned not only with the efficient operation of enterprises, ${ }^{148}$ but also with the vindication of property and contract rights.

148 Moscow Woolen Base v. Troitsky Cloth Factory (State Arbitration of the U.S.S.R. Council of Ministers 1965), [1966] 11 Sov. IvST. 31, discussed in text accompanying notes $39-40$ sipra.

149 Workers, engineers, and technicians! Improve the quality of output in every way, persistently lower its cost! 